\title{
GEOCHEMICAL VARIABILITY IN THE GREENSTONE BELTS OF GOIÁS (BRAZIL): THE HIDROLINA AND ORIXÁS SEQUENCES
}

\author{
GIORGIO RIVALENTI*, MAURIZIO MAZZUCCHELLI*, VICENTE ANTÔNIO VITORIO GIRARDI**, \\ MARIA ÂNGELA FORNONI CANDIA**, MASSIMO COLTORTI***, CIRO TEIXEIRA CORREIA**, \\ FRANCA SIENA**** and CRISTINA FINATTI*
}

\begin{abstract}
RESUMO VARIAÇÃO GEOQUÍMICA NOS CINTURÕES VERDES DE GOIÁS (BRASIL): AS SEQÜÊNCIAS DE HIDROLINA E CRIXÁS. Os cinturões verdes de Crixás e Hidrolina situados no Estado de Goiás podem representar componentes desmembrados de um mesmo corpo ou cinturões adjacentes. Suas seqüências estratigráficas e evoluções tectono-metamórfícas são semelhantes, assim como seus componentes ígneos (metakomatiítos, metabasaltos e metavulcânicas félsicas). Quimicamente, eles diferem no comportamento das relações entre $\mathrm{CaO}$ e $\mathrm{Al}_{2} \mathrm{O}_{3}$ com $\mathrm{MgO}$, e na conduta de vários elementos compatíveis e incompatíveis ( $\mathrm{Cr}, \mathrm{Ni}, \mathrm{Ti}, \mathrm{Sc}, \mathrm{Y}, \mathrm{Zr}, \mathrm{P})$. O comportamento de Ca e Al, anômalo em Crixás, é tentativamente atribuído a um processo de cristalização cujos controles não estão esclarecidos. Tal processo, atuante em Crixás, e não existente em Hidrolina, implicaria na formação de clinopiroxênio em meio a uma massa constituída principalmente por olivina. Ás diferencas no comportamento dos elementos tracos foram atribuídas principalmente à heterogeneidade composicional e modal da fonte mantélica, que foi provavelmente mais rica em espinélio em Crixás do que em Hidrolina.
\end{abstract}

Palavras-chaves: Cinturão de rochas verdes, heterogeneidade mantélica Crixás, Hidrolina, Goiás.

\begin{abstract}
The greenstone belts of Crixás and Hidrolina of Goiás, Brazil, are dismembered components of the same body or of originally adjacent belts. Their tectono-metamorphic history and stratigraphy is similar, as well as their igneous components (meta-komatiites, meta-basalts and felsic meta-volcanics). Chemically, they differ for the $\mathrm{CaO}$ and $\mathrm{Al}_{2} \mathrm{O}_{3}$ versus $\mathrm{MgO}$ trends and for the behaviour of many incompatible and compatible trace elements $(\mathrm{Cr}, \mathrm{Ni}, \mathrm{Ti}, \mathrm{Sc}, \mathrm{Y}, \mathrm{Zr}, \mathrm{P})$. The difference in the $\mathrm{Ca}$ and $\mathrm{Al}$ behaviour, wich is anomalous at Crixás, is tentatively attributed to an unconstrained igneous crystallization process. This process should imply the growth of clinopyroxene into an olivine-dominated crystal mush, and has acted at Crixás and not at Hidrolina. The difference in the trace element behaviour has been mainly attributed to a compositional and modal heterogeneity of the mantle source, which was probably spinel-richer at Crixás than at Hidrolina.
\end{abstract}

Keywords: Greenstone belts, mantle heterogeneity, Crixás, Hidrolina, Goiás.

INTRODUCTION An important feature of greenstone belts are the regional compositional variations of their stratigraphic units. These variations, if primary, may give indications on the variability of the environment of emplacement or of the source of the materials and, if secondary, may be an useful indicator of postgenetic processes.

Regional differences within single units of one greenstone sequence are well documented, for instance, in South-African greenstone belts: Viljoen et al. (1982) have pointed out differences in the Onverwacht group of Barberton between the Sandspruit, Komati, Geluk, Badplaaas and Barberton types.

Two occurrences of Central Goiás (Brazil), the Crixás and Hidrolina greenstone belts are here examined. They are components of the same geological unit: the Pilar de Goiás Group (Ribeiro Filho 1978, Danni \& Ribeiro 1978, Saboia \& Teixeira 1983). Most probably, they belong to the same greenstone belt, dismembered by effect of a complicated tectono-metamorphic history consisting of several deformation episodes, metamorphism and intrusion of granites (Danni et al. 1986). It is also possible that they originally occurred in adjacent but separated belts. They are now divided by intrusive granites about $50 \mathrm{~km}$ apart. They are covered probably in discordance by the Proterozoic formation of the Araxá schists and rest unconformably on an Archaean basement (2.9-3.1 Ga, Almeida \& Hasui 1969, Hasui \& Almeida 1970, Tassinari \& Montalvão 1980) of granitoid, gneisses, migmatites and amphibolites (Danni et al. 1986, Montalvão 1986). Their age is Archaean and probably of 2.7 $2.8 \mathrm{Ga}$ (Arndt et al. 1989).

Literature data (Saboia \& Teixeira 1983) and references therein) and field inspections show that the Hidrolina and Crixás belts have similar stratigraphies. Recent geochemical work, however, has shown that rocks of the same stratigraphic unit in the two sequences may show considerable differences. For instance, Rivalenti et al. (1989) have concluded that the Hidrolina belt has undergone an essentially isochemical metamorphism (except for alkaline elements and alkaline earths) and have proposed an igneous genetic model on this base; on the contrary, Arndt et al. (1989) at Crixás have concluded that the komatiites have undergone extensive element mobilization and that little is leff of the original composition. These differences have prompted us to a comparative study of the two sequences. For this reason, 120 new analyses of the Crixás sequence have been carried out, which are available by request.

Although in the text the prefix "meta-" has been omitted in the terminalogy, obviously all the rocks are metamorphic.

STRATIGRAPHY The stratigraphy of Hidrolina belt is reported in Danni et al. (1986) and Rivalenti et al. (1989) and that of Crixás in Saboia et al. (1979). Rivalenti et al. (1989) have divided the Hidrolina belt into a lower and an upper sequence (LS and US). The LS consists of a basal portion dominated by ultramafic flows intercalated with thin chemical

\footnotetext{
* Instituto di Mineralogia e Petrologia, Università, Largo S. Eufemia 19,41100 Modena, Italia

** Instituto de Geociências, Universidade de São Paulo, Caixa Postal 20899, São Paulo, SP, Brasi

*** Instituto di Mineralogia, Università, C.so. Ercole I d'Este 32,44100 Ferrara, Itália

**** Instituto di Scienze Delia Terra, Università, C.so. Itália 55, Catania, Italia
} 
sediments (LS1), grading upwards into a zone where the ultramafic flows decrease and the mafic flows increase (LS2) until the ultramafics disappear (LS3). Concomitantly the sedimentary component increases. At the roof of LS3 an horizon of marbles occurs and separates the lower unit from US. US igneous componet consists of intercalated basaltic and felsic volcanics. Sediments are pelites and quartzites. The pelitic rocks dominate in the uppermost part where the main Au mineralizations occur (Magalhães et al. 1984, Ribeiro Filho 1984).

At Crixás, Saboia \& Teixeira (1983) ditinguish three units (called by them "formations"): a. the Córrego Alagadinho unit, constituted by ultramafic flows preserving primary features, without sediments; $b$. the Rio Vermelho unit, with dominant basaltic rocks preserving sometimes pillow structures; c. the Ribeirão das Antas unit, dominantly sedimentary (chlorite-quartz schists, quartzites, grafite schists, B IF) and metabasalts interlay ered with felsic metavolcanics.

Recently Jost \& Oliveira (1990) compared the stratigraphy of the three greenstone belts named by them Pilar de Goiás, Guarinos and Crixás. They proposed a new stratigraphy for the supracrustal units and concluded that the differences among them can be explained either by paleogeography or by tectonism. Jost et al. (1989) also described a new stratigraphic unit called Morro Vermelho sequence, which overlays the greenstone units in the Crixás area.

The two stratigraphic successions compare favourably: the Alagadinho unit may correspond with LS1 and LS2, the Rio Vermelho unit is probably analogous to LS3 and the Ribeirão das Antas corresponds with US. A difference is the absence of metasediments in the Crixás basal zone, while the presence of marbles at the top of the Rio Vermelho unit is dubious.

PETROGRAPHY Komatiites The field characteristics and petrology of lhe Crixás komatiites have been been described by Saboia \& Teixeira (1983) and Arndt et al. (1989) and of those of Hidrolina by Danni et al. (1986) and Rivalenti et al. (1989). They have the typical characteristics of ultramafic volcanics metamorphosed under greenschist facies. At Hidrolina, and in a large part of the Crixás field, they are ultramafic schists composed by serpentine, chlorite, tremolite, and variable amounts of carbonate, talc and opaque minerals. Relic primary features are exceptional at Hidrolina (only one pillow occurence) and more common at Crixás in the Córrego Alagadinho section, where individual flows show spinifex textures, olivine cumulates at the bottom of the flows, porphyritic textures, and polyhedral jointing. In the spinifex-textured samples, olivine needles are replaced by tremolite and chlorite with minor carbonate; serpentine occurs in the interstitial matrix. Relics of primary minerals are vey rare and consist of olivine and clinopyroxene. Arndt et al. (1989) mention the occurrence of metamorphic recrystallized olivine.

Basalts They consist in both localities of amphibolites composed by randomly oriented blue-green to yellow-green hornblende, plagioclase, quartz, and sometimes epidote, sphene, carbonate. Opaques and zircon are accessories. Primary volcanic structures (pillow) have been found only at Crixás in the Rio Vermelho section.

CHEMISTRY The XRF analytical methods employed for major and trace elements determinations on the 120 Crixás samples were the same as used at Hidrolina. Details on the methods, accuracy and precision data are reported in Rivalenti et al. (1989).

Average composition of Hidrolina and Crixás komatiites and basalts are reported in tables 1 and 2, respectively. The geochemical trends for major and trace elements of the two localities are compared in the plots of figures 1 to 6 .
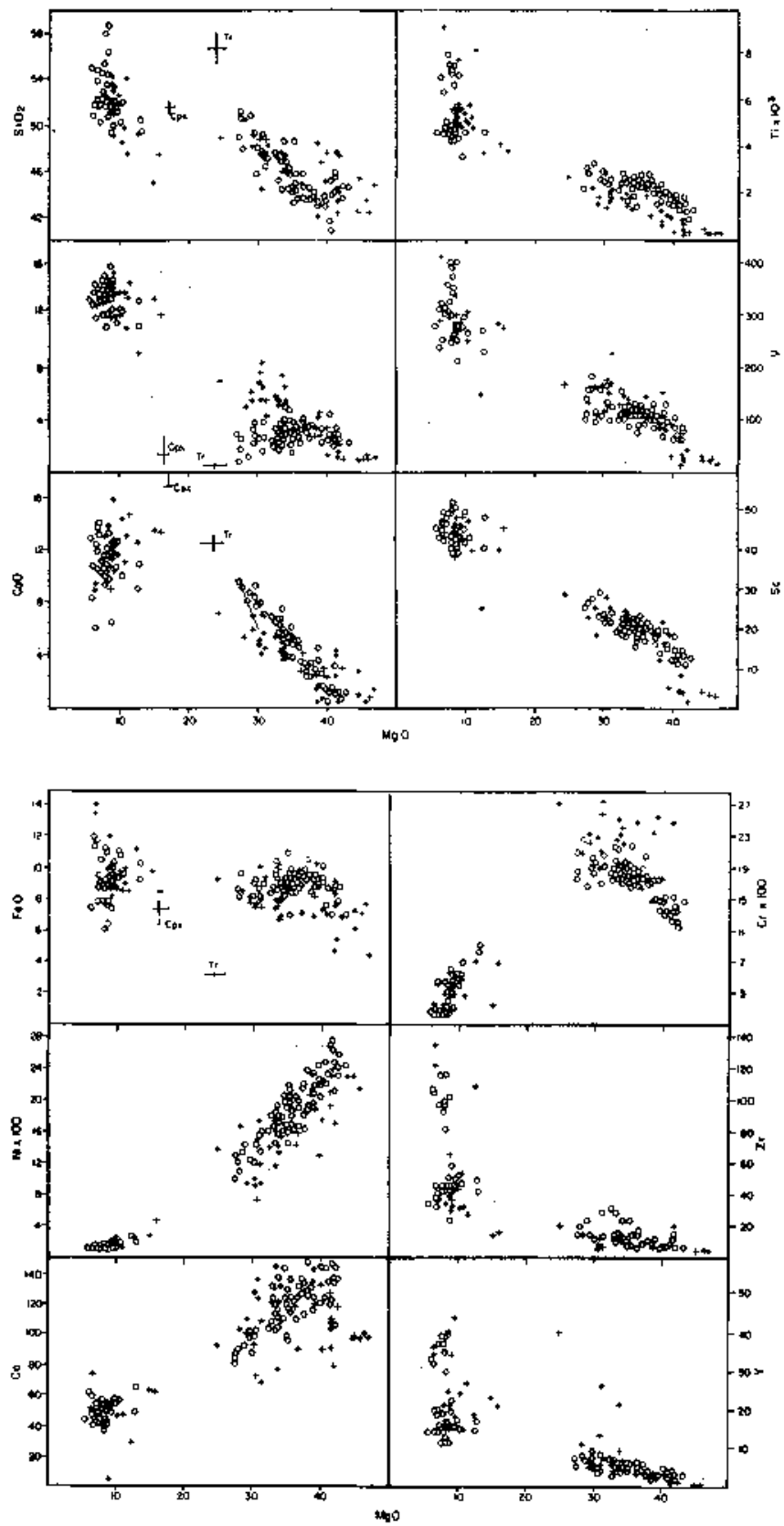

Figure 1 - Plot of $\mathrm{MgO}$ versus $\mathrm{SiO}_{2}, \mathrm{Al}_{2} \mathrm{O}_{3}, \mathrm{CaO}, \mathrm{FeO}$ (wt\%), and $\mathrm{Ti}, \mathrm{Zr}, \mathrm{Y}, \mathrm{Sc}, \mathrm{V}, \mathrm{Ni}, \mathrm{Co}, \mathrm{Cr}$ (ppm)for the samples from the Hidrolina (crosses) and Crixás (circles) greenstone belts, the analyses are recalculated anhydrous. Samples of Hidrolina enriched in cumulus phases (Rivalenti et al. 1989), except those of the komatiites, have been omitted. The compositional range of clinopyroxene relics and of tremolite at Crixás is reported in the $\mathrm{SiO}_{2}, \mathrm{CaO}, \mathrm{Al}_{2} \mathrm{O}_{3}$ plots

Figura 1 - Relação entre $\mathrm{MgO}$ e os óxidos $\mathrm{SiO}_{2}, \mathrm{Al}_{2} \mathrm{O}_{3}, \mathrm{CaO}, \mathrm{FeO}(\%$ peso) e Ti, Zr, Y, Sc, V, Ni, Co, Cr (ppm) para as amostras dos cinturões verdes de Hidrolina (cruzes) e Crixás (círculos). As análises foram recalculadas anidras. As amostras ricas em fases cumulus de Hidrolina (Rivalenti et al. 1989), exceto as dos komatiftos, foram omitidas. As variações composicionais dos relidos de clinopiroxênio e de tremolita de Crixás estão expressas nos diagramas de $\mathrm{SiO}_{2}, \mathrm{CaO}$ e $\mathrm{Al}_{2} \mathrm{O}_{3}$

Komatiites Figure 1 shows that the two occurrences behave for most major elements in the same way, except for $\mathrm{Al}_{2} \mathrm{O}_{3}$ 
Table $l$ - Averages of chemical analysis of the Hidrolina komatiites and basalts (Rivalenti et al.

Tabela 1 - Média de análises químicas dos komatí́tos e basaltos de Hidrolina (Rivalenti ei al. 1989)

\begin{tabular}{|c|c|c|c|c|c|c|c|c|c|}
\hline & \multicolumn{4}{|c|}{ Komatitites } & \multicolumn{5}{|c|}{ Basalts } \\
\hline Str. Unit & $\begin{array}{r}\mathrm{Mg} \mathrm{29-31} \\
\text { LS } 1\end{array}$ & $\begin{array}{c}\mathrm{Mg} 33-34 \\
\text { LS } 1\end{array}$ & $\begin{array}{c}\mathrm{Mg} 38-40 \\
\text { LS } 1\end{array}$ & $\begin{array}{r}\mathrm{Mg} 24 \\
\text { LS } 2\end{array}$ & $\begin{array}{r}M g 7-10 \\
\text { LS } 2\end{array}$ & $\begin{array}{r}\text { Mg 8-11 } \\
\text { LS } 3\end{array}$ & $\begin{array}{c}\text { Mg 14-16 } \\
\text { LS } 3\end{array}$ & $\begin{array}{r}\text { Mg 6-7 } \\
\text { US }\end{array}$ & $\begin{array}{r}\text { Mg 8-11 } \\
\text { US }\end{array}$ \\
\hline $\begin{array}{l}\mathrm{SiO}_{2} \\
\mathrm{TiO}_{2} \\
\mathrm{Al}_{2} \mathrm{O}_{3} \\
\mathrm{Fe}_{2} \mathrm{O}_{3} \\
\mathrm{FeO} \\
\mathrm{MnO} \\
\mathrm{MgO} \\
\mathrm{CaO} \\
\mathrm{Ne}_{2} \mathrm{O} \\
\mathrm{K}_{2} \mathrm{O} \\
\mathrm{P}_{2} \mathrm{O}_{5} \\
\mathrm{CaO}_{\mathrm{Al}_{2} \mathrm{O}_{3}} \\
\mathrm{Al}_{2} \mathrm{O}_{3} / \mathrm{TiO}_{2}\end{array}$ & $\begin{array}{r}47.65 \\
0.28 \\
6.02 \\
1.82 \\
8.21 \\
0.15 \\
30.30 \\
5.38 \\
0.12 \\
0.03 \\
0.04 \\
0.93 \\
22.51\end{array}$ & $\begin{array}{r}46,80 \\
0.27 \\
5,67 \\
1.69 \\
7.59 \\
0.13 \\
33.41 \\
4.32 \\
0.07 \\
0.02 \\
0.03 \\
0.77 \\
21.80\end{array}$ & $\begin{array}{r}45.35 \\
0.19 \\
3.54 \\
1.85 \\
8.34 \\
0.12 \\
38.91 \\
1.68 \\
0.00 \\
0.00 \\
0.02 \\
0.47 \\
17.72\end{array}$ & $\begin{array}{r}48.91 \\
0.44 \\
6.76 \\
2.07 \\
9.32 \\
0.19 \\
24.40 \\
7.31 \\
0.46 \\
0.08 \\
0.07 \\
1.08 \\
15.36\end{array}$ & $\begin{array}{r}52.19 \\
0.92 \\
11.65 \\
2.12 \\
9.53 \\
0.17 \\
8.70 \\
12.81 \\
1.56 \\
0.19 \\
0.15 \\
1.10 \\
12.66\end{array}$ & $\begin{array}{r}51.01 \\
0.87 \\
13.64 \\
1.87 \\
8.40 \\
0.21 \\
8.93 \\
13.61 \\
1.09 \\
0.25 \\
0.12 \\
1.00 \\
15.70\end{array}$ & $\begin{array}{r}46.09 \\
0.65 \\
12.08 \\
2.04 \\
9.18 \\
0.22 \\
15.25 \\
13.44 \\
0.74 \\
0.23 \\
0.10 \\
1.12 \\
18.56\end{array}$ & \begin{tabular}{r|}
51.01 \\
1.61 \\
12.13 \\
3,07 \\
13,82 \\
0.21 \\
6.40 \\
9.17 \\
2.05 \\
0.26 \\
0.26 \\
0.76 \\
7.56
\end{tabular} & $\begin{array}{r}51.69 \\
0.88 \\
12.92 \\
2.12 \\
9.52 \\
0.18 \\
8.93 \\
11.18 \\
2.16 \\
0.28 \\
0.14 \\
0.87 \\
14.79\end{array}$ \\
\hline $\begin{array}{l}\mathrm{P} \\
\mathrm{Se} \\
\mathrm{Ti} \\
\mathrm{V} \\
\mathrm{Cr} \\
\mathrm{Co} \\
\mathrm{Ni} \\
\mathrm{Y} \\
\mathrm{Zr} \\
\mathrm{Ti} / \mathrm{P} \\
\mathrm{TU} \mathrm{Sc} \\
\mathrm{T} \mathrm{V} / \mathrm{V} \\
\mathrm{TU} / \mathrm{Y} \\
\mathrm{T} \mathrm{Z} \mathbf{Z r} \\
\mathrm{Zr} / \mathrm{Sc}\end{array}$ & $\begin{array}{c}135 \\
23 \\
1659 \\
152 \\
2733 \\
103 \\
1081 \\
8 \\
9 \\
11.5 \\
74 \\
11.2 \\
285 \\
338 \\
0.25\end{array}$ & $\begin{array}{c}83 \\
21 \\
1500 \\
127 \\
2363 \\
118 \\
1433 \\
5 \\
6 \\
17.7 \\
66 \\
12.5 \\
283 \\
231 \\
0.30\end{array}$ & $\begin{array}{r}80 \\
18 \\
1110 \\
99 \\
2568 \\
139 \\
1853 \\
2 \\
\overrightarrow{16.5} \\
64 \\
11.2 \\
371 \\
- \\
-\end{array}$ & $\begin{array}{c}305 \\
29 \\
2637 \\
167 \\
2820 \\
92 \\
1370 \\
40 \\
20 \\
8.6 \\
90 \\
15.7 \\
65 \\
131 \\
0.69\end{array}$ & $\begin{array}{c}666 \\
44 \\
5515 \\
282 \\
627 \\
53 \\
177 \\
35 \\
45 \\
8.2 \\
124 \\
19.5 \\
141 \\
121 \\
1.02\end{array}$ & $\begin{array}{c}539 \\
44 \\
5231 \\
287 \\
477 \\
37 \\
151 \\
18 \\
39 \\
9.8 \\
116 \\
18.2 \\
290 \\
137 \\
0.33\end{array}$ & $\begin{array}{c}419 \\
43 \\
3899 \\
276 \\
485 \\
62 \\
360 \\
22 \\
14 \\
9.3 \\
91 \\
14.1 \\
177 \\
280 \\
0.19\end{array}$ & $\begin{array}{c}1156 \\
47 \\
9651 \\
353 \\
239 \\
62 \\
91 \\
35 \\
130 \\
8.6 \\
297 \\
27.9 \\
275 \\
74 \\
2.79\end{array}$ & $\begin{array}{r}612 \\
44 \\
5260 \\
272 \\
357 \\
48 \\
131 \\
16 \\
44 \\
8.4 \\
120 \\
19.3 \\
334 \\
120 \\
1.01\end{array}$ \\
\hline
\end{tabular}

Analysis are recalculate anhydrous. $\mathrm{Fe}_{2} \mathrm{O}_{3}$ has been calculated from total $\mathrm{Fe}$ assuming $\mathrm{Fe}_{2} \mathrm{O}_{3}=0.2 \mathrm{FeO}$. The analyses are averages of the $\mathrm{MgO}$ range indicated in the labels. For instance sample $\mathrm{Mg} 29-31$ is the average of the samples in the range $29<\mathrm{MgO}<31 \%$

and $\mathrm{CaO}$ : in Crixás, the first slightly increases at increasing $\mathrm{MgO}$ in the $\mathrm{MgO}$ range $27 \%-35 \%$, while at Hidrolina it decreases; the second is higher and decreases more sharply at decreasing $\mathrm{MgO}$ in Crixás than in Hidrolina. Figure 2 shows that the $\mathrm{CaO}$ and $\mathrm{AL}_{2} \mathrm{O}_{3}$ trends of the Crixás komatiites occur in single flows: $\mathrm{CaO}$ reaches a maximum concentration in the spinifex-textured centre of the flow; $\mathrm{A}_{2} \mathrm{O}_{3}$ varies little, but decreases slightly at the centre, as does also $\mathrm{MgO}$.

Other differences between Crixás and Hidrolina are a higher content of $\mathrm{Ni}, \mathrm{Ti}$ and $\mathrm{Y}$ in the first locality at a given $\mathrm{MgO}$ content. So behaves also $\mathrm{Zr}$, but its content spreads much in the komatiites of Crixás. Cr shows a hump-shaped trend at Crixás, with a maximum at about $35 \% \mathrm{MgO}$, and is tendentiously lower than in Hidrolina, where it exhibits a dispersed array.

All the ratios where $\mathrm{Ti}$ is involved $(\mathrm{Ti} / \mathrm{Zr}, \mathrm{Ti} / \mathrm{Y}, \mathrm{Ti} / \mathrm{V}$ and $\mathrm{Ti} / \mathrm{Sc}$ ) are different in the two localities. Figure 3,4 and 5 and tables 1 and 2 show that in the komatiites of Crixás the ratios $\mathrm{Ti} / \mathrm{Zr}, \mathrm{Ti} / \mathrm{Y}, \mathrm{Ti} / \mathrm{V}$ and $\mathrm{Ti} / \mathrm{Sc}$ are higher than chondritic, $\mathrm{Zr} / \mathrm{Sc}$ is lower and $\mathrm{Zr} / \mathrm{Y}$ and $\mathrm{Sc} / \mathrm{Y}$ are at about chondritic. At Hidrolina, in $\mathrm{Pk} \mathrm{Ti} / \mathrm{Zr}$ is higher, $\mathrm{Ti} / \mathrm{V}$ and $\mathrm{Zr} / \mathrm{Sc}$ are lower, while all the other ratios are at about chondritic. The $\mathrm{Al}_{2} \mathrm{O}_{3} / \mathrm{TiO}_{2}$ ratio (Tabs. 1 and 2) is much lower than the chondritic values of 20 in all the Crixás rocks, whereas at Hidrolina, it is chondritic or slightly lower than chondritic.

The differences between the two localities are stressed by the zero intercepts on the $\mathrm{MgO}$ axis incompatible elements and by the molecular proportion ratio (MPR) plots of figure 6. The zero intercepts for $\mathrm{CaO}, \mathrm{Ti}, \mathrm{Y}$ and $\mathrm{Sc}$ are at $\mathrm{MgO} 43 \%, 48 \%, 56 \%$ and $58 \%$, respectively in Crixás and at $47 \%, 46 \%, 36 \%$ and $46 \%$ in Hidrolina. While in Hidrolina they are closer, except for Y, to a possible olivine control line (which would give intercepts at about $\mathrm{MgO} 47 \%-50 \%$ ), this is not the case in Crixás, except for Ti.

MPR trends (for their use, see Pearce 1968,1987, Beswick 1982, Rollinson \& Roberts 1986, Russel \& Nicholls 1988) are compared in figure 6 . Although fairly parallel, the trends of the komatiites of the two localities are clearly distinguished, thus suggesting a control of the same phase (s), but different initial compositions. The controlling assemblage of the komatiite trend appears to be olivine dominated.

Basalts The basaltic rocks of Crixás, as those of Hidrolina, have the characteristics of tholeiites (Tabs. 1 and 2 ). They cluster into two groups distinguished by a Ti content higher and lower than $0.6 \%$ (Figs. 1 and 3 ). The higher Ti correlates with higher $\mathrm{P}, \mathrm{Zr}, \mathrm{V}$ and $\mathrm{Y}$ and lower Sc. These clusters apparently do not correspond with any stratigraphic division. Samples enriched in Ti are found also at Hidrolina in the US unit. At Hidrolina, in the $\mathrm{MgO}$ range $9 \%-12 \%$, the basalts contain more Ti (Fig. 1 and Tabs. 1 and 2). In the same range, the rocks of Crixás have lower Ti/Sc and higher $\mathrm{Zr} / \mathrm{P}$ than those of Hidrolina, while $\mathrm{Ti} / \mathrm{P}, \mathrm{Ti} / \mathrm{Zr}, \mathrm{Ti} / \mathrm{Y}, \mathrm{Zr} / \mathrm{Sc}$ and $\mathrm{Zr} / \mathrm{Y}$ are similar and $\mathrm{Ti} / \mathrm{V}$ is slightly lower (Figs. 2 to 4 ). Ti/P and $\mathrm{Sc} / \mathrm{Y}$ are lower than chondritic, while $\mathrm{Ti} / \mathrm{Zr}, \mathrm{Ti} / \mathrm{Y}, \mathrm{Zr} / \mathrm{Y}$ are at about chondritic and $\mathrm{Zr} / \mathrm{Sc}$ is higher. In the high $\mathrm{Ti}$ 
Table 2 - Averages of chemical analysis of the Crixás komatiites and basalts

Tabela 2 - Médias das análises químicas de komatítos e basaltos de Crixás

\begin{tabular}{|c|c|c|c|c|c|c|c|c|c|c|c|}
\hline \multirow[t]{2}{*}{ Str. Unit } & \multicolumn{6}{|c|}{$\begin{array}{l}\text { Komatiites } \\
\text { Córrego Alngadinho }\end{array}$} & \multicolumn{5}{|c|}{$\begin{array}{l}\text { Basalts } \\
\text { Rio Vernolho and Ribehtio das Antas }\end{array}$} \\
\hline & $\mathrm{Mg} 27-29$ & Mg 29-31 & Mg 31-33 & Mg 33-36 & $\mathrm{Mg}$ 36-38 & $\mathrm{Mg} 38-40$ & $\begin{array}{l}\text { Mg 7-9 } \\
\text { Low Ti }\end{array}$ & $\begin{array}{c}\mathrm{Mg} 9-11 \\
\text { Low Ti }\end{array}$ & $\begin{array}{c}\text { Mg } 11-13 \\
\text { Low Ti }\end{array}$ & $\begin{array}{l}\text { Mg 6-7 } \\
\text { High Ti }\end{array}$ & $\begin{array}{l}\mathrm{Mg} 7 \cdot 8 \\
\text { High Tt }\end{array}$ \\
\hline $\begin{array}{l}\mathrm{SiO}_{2} \\
\mathrm{TiO}_{2} \\
\mathrm{Al}_{2} \mathrm{O}_{3} \\
\mathrm{Fe}_{2} \mathrm{O}_{3} \\
\mathrm{FeO} \\
\mathrm{MnO} \\
\mathrm{MgO} \\
\mathrm{CaO} \\
\mathrm{Na} \mathrm{O} \\
\mathrm{K}_{2} \mathrm{O} \\
\mathrm{P}_{2} \mathrm{O}_{5} \\
\mathrm{CaO} / \mathrm{Al}_{2} \mathrm{O}_{3} \\
\mathrm{Al}_{2} \mathrm{O} / \mathrm{TO}_{2}\end{array}$ & $\begin{array}{r}47.79 \\
0.45 \\
2.80 \\
2.14 \\
9.65 \\
0.14 \\
27.77 \\
9.06 \\
0.12 \\
0.03 \\
0.04 \\
3.62 \\
6.08\end{array}$ & $\begin{array}{r}47.81 \\
0.43 \\
2.66 \\
1.93 \\
8.67 \\
0.14 \\
30.00 \\
8.24 \\
0.04 \\
0.02 \\
0.07 \\
3.33 \\
6.08\end{array}$ & $\begin{array}{r}45.71 \\
0.40 \\
3.34 \\
2.17 \\
9.78 \\
0.15 \\
32.06 \\
6.32 \\
0.00 \\
0.02 \\
0.06 \\
1.89 \\
8.23\end{array}$ & $\begin{array}{r}45.81 \\
0.35 \\
3.28 \\
1.93 \\
8.68 \\
0.16 \\
34.56 \\
5.15 \\
0.03 \\
0.01 \\
0.03 \\
1.73 \\
9.39\end{array}$ & $\begin{array}{r}44.34 \\
0.35 \\
3.02 \\
2.08 \\
9.37 \\
0.18 \\
37.03 \\
3.59 \\
0.00 \\
0.01 \\
0.03 \\
1.24 \\
\iota_{2} .6\end{array}$ & $\begin{array}{r}43.33 \\
0.27 \\
2.85 \\
2.09 \\
9.40 \\
0.19 \\
39.10 \\
2.72 \\
0.01 \\
0.01 \\
0.03 \\
0.99 \\
10.51\end{array}$ & \begin{tabular}{|r|}
53.51 \\
0.73 \\
13.01 \\
1.93 \\
8.67 \\
0.18 \\
8.11 \\
10.87 \\
2.67 \\
0.21 \\
0.11 \\
0.84 \\
17.78
\end{tabular} & $\begin{array}{r}51.46 \\
0.84 \\
11.59 \\
2.31 \\
10.39 \\
0.18 \\
9.89 \\
11.14 \\
1.96 \\
0.13 \\
0.11 \\
0.96 \\
13.84\end{array}$ & $\begin{array}{r}49.97 \\
0.70 \\
11.76 \\
2.21 \\
9.93 \\
0.17 \\
12.83 \\
9.96 \\
2.26 \\
0.10 \\
0.11 \\
0.85 \\
16.84\end{array}$ & $\begin{array}{r}51.65 \\
1.44 \\
13.17 \\
2.65 \\
11.92 \\
0.20 \\
6.23 \\
8.46 \\
3.73 \\
0.26 \\
0.29 \\
0.64 \\
9.15\end{array}$ & $\begin{array}{r}51.85 \\
1.22 \\
13.20 \\
2.28 \\
10.25 \\
0.17 \\
7.86 \\
10.40 \\
2.29 \\
0.30 \\
0.19 \\
0.79 \\
10.82\end{array}$ \\
\hline $\begin{array}{l}\mathrm{P} \\
\mathrm{Sc} \\
\mathrm{Ti} \\
\mathrm{V} \\
\mathrm{Cr} \\
\mathrm{Co} \\
\mathrm{Ni} \\
\mathrm{Y} \\
\mathrm{Zr} \\
\mathrm{Ti} / \mathrm{P} \\
\mathrm{Ti} / \mathrm{Sc} \\
\mathrm{Ti} / \mathrm{V} \\
\mathrm{T} / \mathrm{Y} \\
\mathrm{T} \mathrm{Z} / \mathrm{Zr} \\
\mathrm{Zr} / \mathrm{Sc}\end{array}$ & $\begin{array}{c}187 \\
25 \\
2713 \\
145 \\
2268 \\
91 \\
1158 \\
5 \\
22 \\
14.4 \\
108 \\
18.7 \\
542 \\
121 \\
0.89\end{array}$ & $\begin{array}{c}287 \\
24 \\
2604 \\
118 \\
1982 \\
98 \\
1281 \\
5 \\
7 \\
9.1 \\
110 \\
22.1 \\
504 \\
363 \\
0.30\end{array}$ & $\begin{array}{c}243 \\
23 \\
2425 \\
136 \\
2210 \\
116 \\
1505 \\
4 \\
20 \\
10,0 \\
105 \\
17.8 \\
692 \\
121 \\
0.87\end{array}$ & $\begin{array}{c}138 \\
20 \\
2091 \\
105 \\
1932 \\
113 \\
1732 \\
5 \\
11 \\
15.1 \\
102 \\
19.9 \\
429 \\
184 \\
0.56\end{array}$ & $\begin{array}{c}121 \\
19 \\
2106 \\
101 \\
1904 \\
122 \\
1844 \\
4 \\
14 \\
17.3 \\
110 \\
20.8 \\
481 \\
146 \\
0.76\end{array}$ & $\begin{array}{c}110 \\
16 \\
1636 \\
82 \\
2044 \\
130 \\
2065 \\
3 \\
6 \\
14.8 \\
105 \\
20.0 \\
545 \\
284 \\
0,37\end{array}$ & $\begin{array}{c}461 \\
46 \\
4387 \\
274 \\
335 \\
48 \\
115 \\
14 \\
39 \\
9.5 \\
95 \\
16.0 \\
308 \\
112 \\
0.85\end{array}$ & $\begin{array}{c}486 \\
45 \\
5020 \\
279 \\
647 \\
54 \\
137 \\
29 \\
48 \\
10.3 \\
111 \\
18.0 \\
175 \\
104 \\
1.07\end{array}$ & $\begin{array}{c}478 \\
44 \\
4187 \\
251 \\
993 \\
57 \\
180 \\
16 \\
45 \\
8.7 \\
94 \\
16.7 \\
265 \\
93 \\
1.02\end{array}$ & $\begin{array}{c}1261 \\
40 \\
8633 \\
289 \\
168 \\
57 \\
111 \\
42 \\
167 \\
6.8 \\
213 \\
29.9 \\
207 \\
51 \\
4.13\end{array}$ & $\begin{array}{c}834 \\
43 \\
7309 \\
356 \\
190 \\
52 \\
150 \\
37 \\
101 \\
8.7 \\
168 \\
20.5 \\
199 \\
72 \\
2,32\end{array}$ \\
\hline
\end{tabular}

Analysis are recalculate anhydrous. $\mathrm{Fe}_{2} \mathrm{O}_{3}$ has been calculated from total $\mathrm{Fe}$ assuming $\mathrm{Fe}_{2} \mathrm{O}_{3}=0.2 \mathrm{FeO}$. The analyses are averages of the $\mathrm{MgO}$ range indicated in the labels. For instance sample $\mathrm{Mg} 27-29$ is the average of the samples in the range $27<\mathrm{MgO}<29 \%$

samples $\mathrm{Ti} / \mathrm{Zr}$ and $\mathrm{Ti} / \mathrm{Y}$ become lower than chondritic, while $\mathrm{Zr} / \mathrm{Y}$ is higher.

DISCUSSION The comparison of the chemical parameters between Crixás and Hidrolina has shown that the most significant differences involve $\mathrm{CaO}$ and $\mathrm{A}_{2} \mathrm{O}_{3}$ for the major elements of the komatiites and many compatible and incompatible trace elements of komatiites and basalts. As will be discussed later on, the differences in the trace elements suggest a possible heretogeneity in the source of the two regions. Those concerning $\mathrm{CaO}$ and $\mathrm{Al}_{2} \mathrm{O}_{3}$ are not of easy interpretation. They are dependent on the "anomalous" behaviour of these elements at Crixás and, therefore, this point is to be discussed preliminarly.

$\mathrm{CaO}$ and $\mathrm{AI}_{2} \mathrm{O}_{3}$ behaviour at Crixás The "anomalous" $\mathrm{CaO}$ and $\mathrm{Al}_{2} \mathrm{O}_{3}$ trends of the komatiites at Crixás may depend on the metamorphic redistribution of these elements, or may be primary. In this last case it may be determinated either by mixing of magmas of different initial composition dependent on local heterogeneities of the source or by crustal contamination of the magmas or by the emplacement and crystallization processes.

Metamorphism Arndt et al. (1989) have concluded that the Crixás komatiites have undergone a poorly understood metamorphic or metasomatic process during which the concentration of $\mathrm{CaO}$ and $\mathrm{Al}_{2} \mathrm{O}_{3}$, as well as that of many other elements generally considered as immobile, was drastically changed. There are, however, two main reasons suggesting that hardly metamorphic open system processes are responsible for a $\mathrm{CaO}$ and $\mathrm{Al}_{2} \mathrm{O}_{3}$ redistribution.

The first is a comparison with Hidrolina. The two localities, at a given $\mathrm{MgO}$ content of the rock, have similar mineral assemblages. Moreover, if metamorphic element redistribution has occured, it is more likely that it has taken place at Hidrolina, where primary features have been completely blurred, than at Crixás, where primary features are common.

The second reason rests on the following observations. In the $\mathrm{A}_{2} \mathrm{O}_{3}$ and $\mathrm{CaO}$ plots, the Crixás samples plot towards the clinopyroxene or tremolite composition (Fig. 1). If controlled by tremolite, the system must have been opened at least for $\mathrm{CaO}$ and $\mathrm{SiO}_{2}$, which could have been transported and enriched by hydrothermal solutions and reacted with serpentine or talc to form tremolite. However, the element distribution through single flows should imply that metasomatism has acted more at the centre than at the contacts, and no serious reason can be found for this process.

Mixing of magmas of different composition The possibility that magmas coming from sources of different compositions 


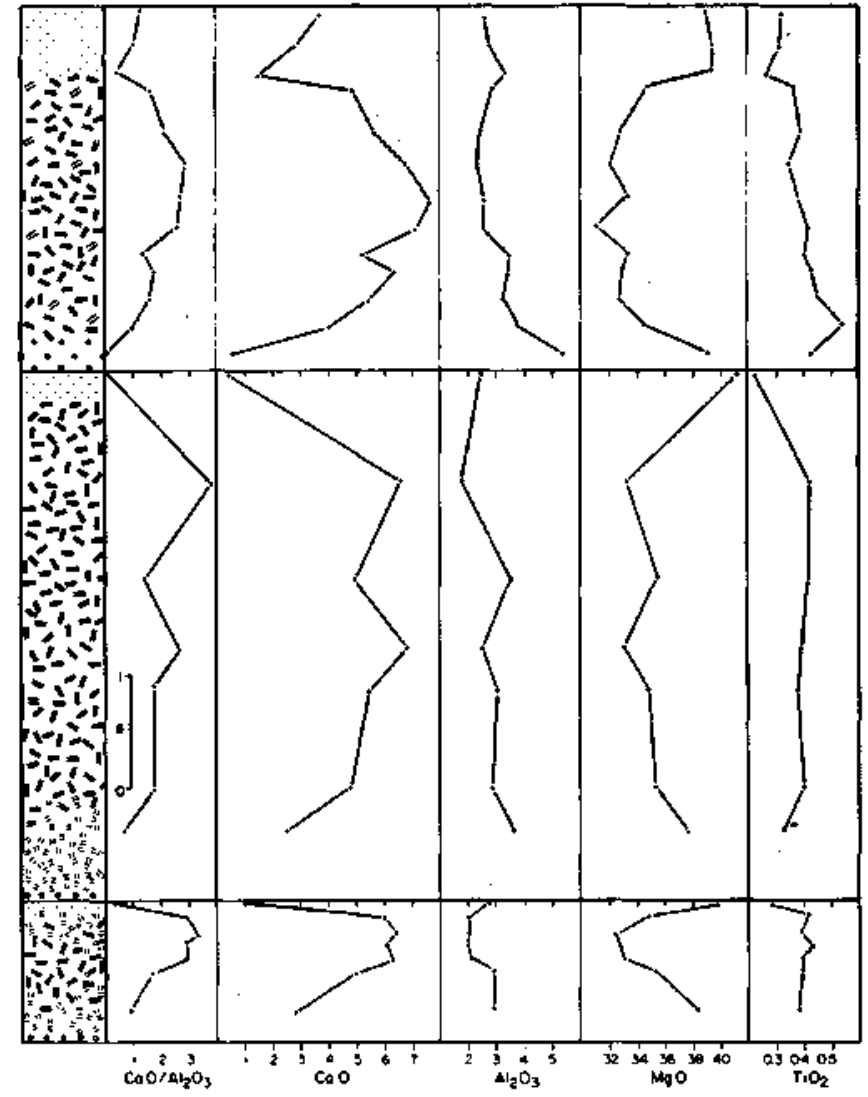

Figure 2 - Variation of $\mathrm{CaO}, \mathrm{Al}_{2} \mathrm{O}_{3}, \mathrm{MgO}, \mathrm{TiO}_{2}$ (wt\%) and of the $\mathrm{CaO} / \mathrm{Al}_{2} \mathrm{O}_{3}$ ratio in three komatiite flows of Crixás (Córrego Alagadinho section). Each flow has an olivine-cumulate zone at the base, is spinifex-textured in the inner pan and has an aphanitic, sometimes polyhedrally-jointed, top. Spinifex dimension becomes decimetric at the centre of the flows

Figura 2 - Variação de $\mathrm{CaO}, \mathrm{Al}_{2} \mathrm{O}_{3}, \mathrm{MgO}, \mathrm{TiO}_{2}$ (\%peso) e da relação $\mathrm{CaO} / \mathrm{Al}_{2} \mathrm{O}_{3}$ nos três derrames komatiítícos de Crixás (seção do Córrego do Alagadinho). Cada derrame tem cumulato de olivina na base, textura spinifex na parte central, e é afanítíca, às vezes com disjunção poliedral no topo. As dimensões do spinifex tornam-se decimétricas no centro dos derrames

are mixed to give the actual variation patterns is ruled out by the fact that single flows display the whole $\mathrm{CaO}$ and $\mathrm{Al}_{2} \mathrm{O}_{3}$ variation range: as Arndt et al. (1989) claim, although it might be theoretically possible to mix magmas from different sources within a single flow, it seems highly improbable that this process is repeated at each flow.

Contamination In order to establish a possible contaminant, a mass balance calculation has been carried out. The average at 27\%-20\% $\mathrm{MgO}$ and $33 \%-36 \% \mathrm{MgO}$ have been considered as end-members. As a constraint for the calculation, it has been assumed that neither the crystallizing phase (which, in this $\mathrm{MgO}$ range, can be only olivine) nor the contaminant contained $\mathrm{CaO}$.

The lack of $\mathrm{CaO}$ in the contaminant is postulated on the basis of the rapid decrease of $\mathrm{CaO}$ at increasing $\mathrm{MgO}$ (Fig. 1), resulting in a much lower $\mathrm{MgO}$ zero intercept than that expected from olivine control.

The residue (Tab. 3) from subtracting the high $\mathrm{MgO}$ group from the low one, until $\mathrm{CaO}$ is minimized, can be recalculated

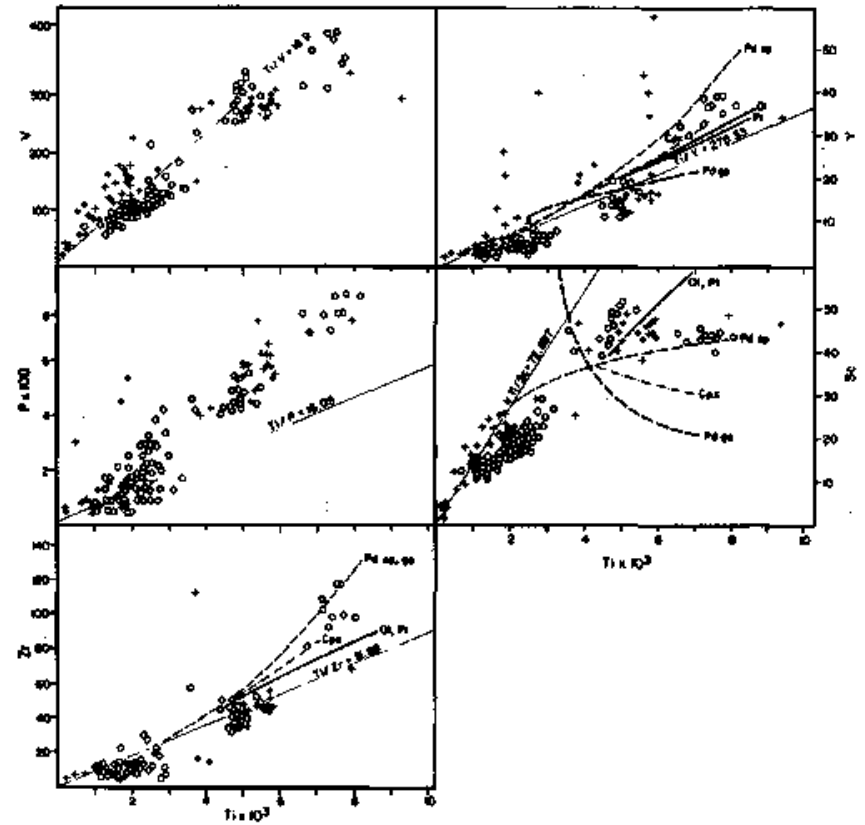

Figure 3 - Plot of Ti versus $Z r, P, V$, Sc and $Y$ (ppm)for the rocks of Hidrolina (crosses) and Crixás (circles). Chondrite values (continuous line) are from Wänke et al. (1974), Jagoutz et al. (1979), Wood (1979) and Nesbitt \& Sun (1980). The $\mathrm{Zr}, \mathrm{Sc}$, and $\mathrm{Ti} / \mathrm{Sc}$ concentration calculated in liquids formed by non modal partial melting of mantle in garnet- or spinel-peridotite fades is also reported (dashed lines; ticks are intervals of $5 \%$ melting). Model mantle (asterisk) is that of Hofrnann (1989). The formula used is: $C_{1}=C_{d} /[D=F(1-P)]$, where $\mathrm{C}$, is the concentration of the element in the liquid; $C_{O}$ is the concentration in the source, $D$ is the bulk partition coefficient for the source; $P$ is the bulk partition coefficient for the melting assemblage; $F$ is the melting degree. Partition coefficients are from Rivalenti et al. (1989) Garnet-peridotite (Pd ga) - Modal composition: ol =0.6, opx $=02 ; c p x-0.1 ; g a=0.1$. Melting proportions: ol =0.15, $o p x=0.05 ; c p x=0.4 ; g a=0.4$, Spinel-peridotite $(P d s p)$ Modal composition: $o l=0.6 ;$ opx $=02 ; c p x=0.15 ; s p=$ 0.05 . Melting proportions: $o l=0.15$, opx $=0.75, c p x=0.4$, $s p=03$. Dash-dots lines are fractionation vectors for olivine, clinopyroxene and plagioclase. Ticks are 0,1 fractionation intervals. The formula used is: $\mathrm{C}_{1}=C_{O} * F^{(D-1)}$, Figura 3 - Diagrama de variação de Ti em relação a Zr, P, V, Sc e Y (ppm) para as rochas de Hidrolina (cruzes) e de Crixás (círculos). Os valores condrftícos (linha contínua) são de Wãnke et al. (1974), Jagoutz et al. (1979), Wood (1979) e Nesbitt \& Sun (1980). As concentrações de $\mathrm{Zr}$, Sc e Ti/Sc calculadas nos líquidos formados por fusão não-modal do manto nas facies de granada e espinélio peridotito são também representadas (linhas interrompidas; pequenas marcas são intervalos de fusão de 5\%). O modelo de manto é extraído de Hofmann (1989). A fórmula usada e: $C_{1}=C o /[D+F(1-P)]$, onde $C$, é a concentração do elemento no líquido, Co é a concentração da fonte, $\mathrm{P}$ é o coeficiente de partição total para a assembléia de fusão, F é o grau de fusão. Os coeficientes de partição são de Rivalenti et al. (1989). Granada-Peridotíto (Pd ga) - Composição modal: ol=0,6; opx=0,2; $\mathrm{cpx}=0,1 ; \mathrm{ga}=0,1$. Proporções de fusão: $\mathrm{ol}=0,15 ; \mathrm{opx}=0,05 ; \mathrm{cpx}=$ 0,$4 ; \mathrm{ga}=0,4$. Espinélio peridotito (Pd sp) - Composição modal: ol = 0,$6 ;$ opx $-0,2 ; \mathrm{cpx}=0,15 ; \mathrm{sp}=0,05$. Proporções de fusão: $01=$ 0,$15 ; \mathrm{opx}=0,15 ; \mathrm{cpx}=0,4 ; \mathrm{sp}=0,3$. Linhas interrompidas pontílhadas são vetores de fracionamento para olivina, clinopiroxênio e plagioclásio. Pequenas marcas representam intervalos de fracionamento de 0,1 . A fórmula usada é: $\mathrm{C}_{1}=\mathrm{C}_{0} * \mathrm{~F}^{(\mathrm{D}-1)}$. 


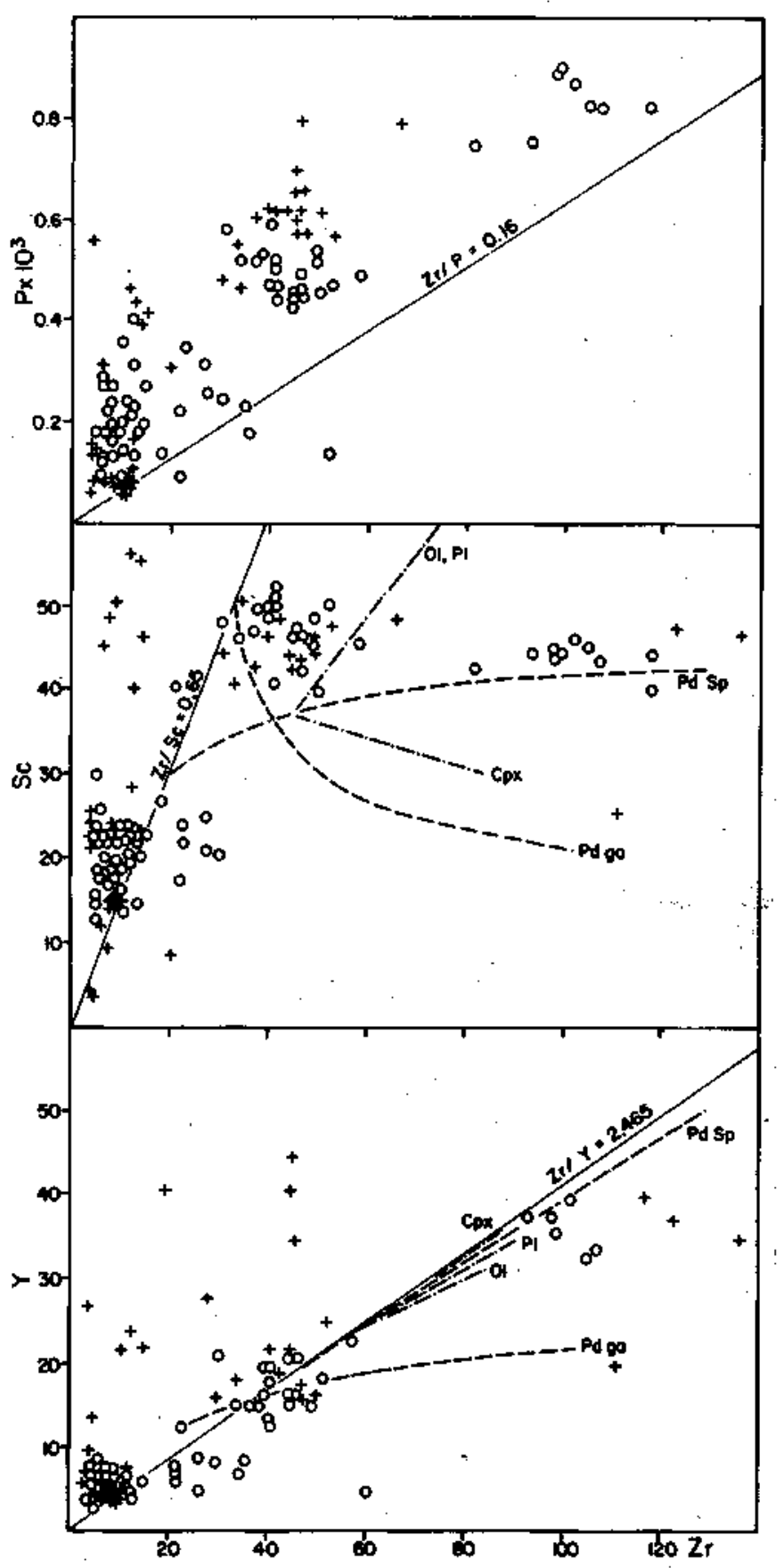

Figure 4 - Plot of $\mathrm{Zr}$ versus $P$, Sc, and $Y$ (ppm), for the samples from the Hidrolina (crosses) and Crixás (circles) greenstone belts. See the caption of figure 3 for the chondrite values, the model melting curves and for the fractionation vectors

Figura 4 - Variação de $Z r$ versus $P$, Sc e $Y$ (ppm), para as amostras dos cinturões verdes de Hidrolina (cruzes) e de Crixás (círculos). Veja a legenda da figura 3 para os valores condrftícos, para as curvas de modelo de fusão e para os vetores de fracionamento

as $88 \%$ olivine and $12 \%$ of a mixture of $9 \%$ clay $(\mathrm{Si}: \mathrm{Al}=1: 2)$ $+3 \%$ quartz. The clay + quartz component could correspond to a normal lateritic rock assimilated by the komatiites during olivine fractionation. This mechanism is, however, unsuported by the trace elements behaviour: such a mixture whould contain negligible amounts of $\mathrm{Y}$ and $\mathrm{Sc}$, and should produce for these elements $\mathrm{MgO}$ intercept sensibly lower than that determined by olivine fractionation, and not higher as in the present case.
Table 3 - Mass balance calculation between the analyses in which $\mathrm{MgO}$ ranges from 27 to $29 \%$ and from 33 to $36 \%$ for the Crixás komatiites

Table 3 - Cálculo de balanço de massa entre as análises nas quais $\mathrm{MgO}$ varia de 27 a $29 \%$ e de 33 a $36 \%$ para os komatiftos de Crixás

\begin{tabular}{|l|r|r|r|}
\hline & Mg 27-29 & Mg 33-36 & \multicolumn{1}{c|}{ Residue } \\
\hline $\mathrm{SiO}_{2}$ & 47.79 & 45.81 & 43.24 \\
$\mathrm{TiO}_{2}$ & 0.45 & 0.35 & 0.22 \\
$\mathrm{Al}_{2} \mathrm{O}_{3}$ & 2.80 & 3.28 & 3.90 \\
$\mathrm{Fe}_{2} \mathrm{O}_{3}$ & 2.14 & 1.93 & 1.66 \\
$\mathrm{FeO}$ & 9.65 & 8.68 & 7.42 \\
$\mathrm{MnO}$ & 0.14 & 0.16 & 0.19 \\
$\mathrm{MgO}$ & 27.77 & 34.56 & 43.38 \\
$\mathrm{CaO}$ & 9.06 & 5.15 & 0.07 \\
\hline
\end{tabular}

No $\mathrm{CaO}$ is assumed in the residue.

Emplacement and crystallization The trends towards the clinopyroxene composition (Fig. 1), as an alternative to tremolite, suggest its possible control. However, the examined single flows have an $\mathrm{MgO}$ content which prohibits early clinopyroxene crystallization either as cumulus or as spinifex. Virtually all the basaltic magmas with more than $12 \% \mathrm{MgO}$ would have olivine as the only liquidus phase on a wide $\mathrm{P}$ range (Green et al. 1975, Arndt 1976, Kinzler \& Grove 1985). Speculatively, a process consisting of the following steps could be proposed:

a. picritic magma crystallizes olivine during ascent;

b. effusion, with consequent chilling at the contacts, of a crystal mush of olivine and residual liquid retaining $10 \%-12 \%$ $\mathrm{MgO}$;

c. crystallization of ol-spinifex, depleting further the residual liquid in $\mathrm{MgO}$, and entry of clinopyroxene;

d. removal during flow of the basaltic residue, which continues crystallizing clinopyroxene.

The amount of clinopyroxene crystallized is in this model directly related to the amount of residual liquid with respect to the solid (olivine) and is expected to be maximum at the centre of the flow. Whether such a process is realistic is very doubtful as no natural occurrence where this happens has ever been described. An indirect support to the possibility that the liquid interstitial to olivine has a basaltic composition, capable of crystallizing clinopyroxene, comes, however, from the studies of Nisbet et al. (1987) and Aitken \& Echeverria (1984), who show that in relatively fresh komatiites the interstitial glass has constantly a basaltic to andesitic composition. In any case, if operative at Crixás, there is no evidence that this process has been efficient also at Hidrolina.

Regional source heterogeneities The non-modal partial melting trends (parameters reported in the figure captions) of a mantle in spinel peridotite and garnet-peridotite fades, having the composition of the undepleted primitive mantle model of Hofmann (1988) ate reported in the plots of figures 3,4 and 5 .

At Hidrolina, Rivalenti et al. (1989) have concluded that: a. the komatiites may have formed by mixing with, and assimilation of mantle material, by a liquid deriving from moderate melting degrees; $b$. melting involved a source in spinel-peridotite facies; c. the mantle source was slightly depleted in imcompatible elements.

Also at Crixás the samples follow a curve suggesting a spinel-, rather than garnet-facies source; the komatiites, plotting close to the source composition, may derive either by improbable extremely high melting degrees $(50 \%-70 \%)$ or, like in Hidrolina, by mixing of liquid formed at moderate melting degrees with mantle material.With respect tcTthe model mantle of Hofmann (1988), the Crixás source was 


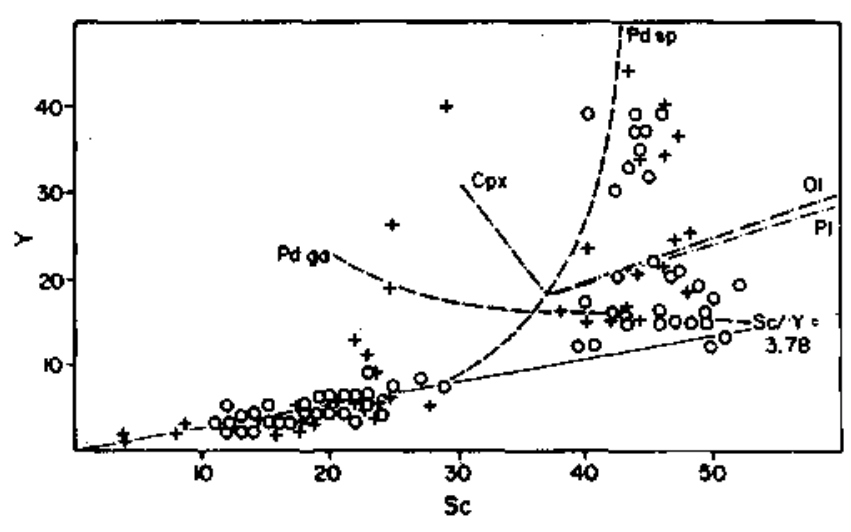

Figure 5-Plot of Sc versus $Y$ ( $\mathrm{ppm}$ ) for the samples the Hidrolina (crosses) and Críxás (circles) greenstone belts. See the caption of figure 3 for the chondritic values, the model melting curves and for the fractionation vectors Figura 5 - Variação de Sc versus Y (ppm) para as amostras dos cinturões verdes de Hidrolina (cruzes) e Críxás (círculos). Veja a legenda da figura 3 para os valores condríícos, para as curvas de modelo de fusão e vetores de fracionatnento

probably depleted in $\mathrm{Zr}, \mathrm{Sc}, \mathrm{Y}$ and $\mathrm{Ti}$.

The systematic differences from the Hidrolina suite, shown in the Ti-Sc, Ti-Zr, Ti-Y, Ti-V, Zr-Y, Zr-Sc and $\mathrm{Zr}-\mathrm{P}$ plots, point to a different composition for the Crixás source. Of particular interest is the contrasting behaviour of the $\mathrm{Ti} / \mathrm{Sc}, \mathrm{Ti} / \mathrm{Y}$ and $\mathrm{Ti} / \mathrm{Zr}$ ratios between komatiites and basalts of Crixas and Hidrolina: in the Crixás komatiites they are higher, and in the basalts they are lower, with respect to Hidrolina. This fact may be accounted for a higher spinel content of the Crixás source: since partition coefficients for this phase are higher for $\mathrm{Ti}$ than for $\mathrm{Zr}, \mathrm{Y}$ and $\mathrm{Sc}$, liquids deriving from moderate $(10 \%-30 \%)$ melting would be enriched in $\mathrm{Sc}, \mathrm{Zr}$ and $\mathrm{Y}$ with respect to $\mathrm{Ti}$, whereas the contrary happens in the melting residue. The different behaviour of $\mathrm{V}$ in the Crixás and Hidrolina komatiites is more difficult to be explained. The bulk partition coefficient for this element is strongly dependent, besides mineralogy, from $\mathrm{fO}_{2}$ (Shervais 1982) and decreases by a factor of 100 for an increase of $\log \mathrm{fO}_{2}$ from -12 to -6 . The higher Ti/V ratio in the Crixás komatiites and slightly lower in the basalts with respect to Hidrolina suggests, therefore, a higher $\mathrm{fO}_{2}$ in the first locality.

Like at Hidrolina, the low-Ti basaltic cluster of Crixás is compatible with a moderate degree $(20 \%-30 \%)$ melting of the same source which gave the komatiites. Its Sc-Ti trend could, however, be consistent with olivine fractionation, but this is excluded as a main control by the small and random variation range of $\mathrm{MgO}$ in this group (Fig. 1). The high-Ti cluster of Crixás might represent lower melting degrees of the same mantle source as that of the low-Ti basaltic cluster (Figs. 3,4 and 5). The samples have, however, low $m g$ numbers if compared with primary mantle-derived liquids. The fractionation vectors of figures 3, 4 and 5 indicate that they may derive by fractionation of clinopyroxene, accompanied by olivine and/or plagioclase, from the low-Ti group. A similar conclusion was reached also on the basalts of Hidrolina. For the rest, the differences between the basalts of the two localities may be accounted for the already discussed heterogeneities of the respective sources.

CONCLUSIONS Although remarkably similar in many stratigraphic and geochemical respects, the Crixás and Hidrolina greenstone belts show differences which are related in part to a regional variation of the mantle source composition.
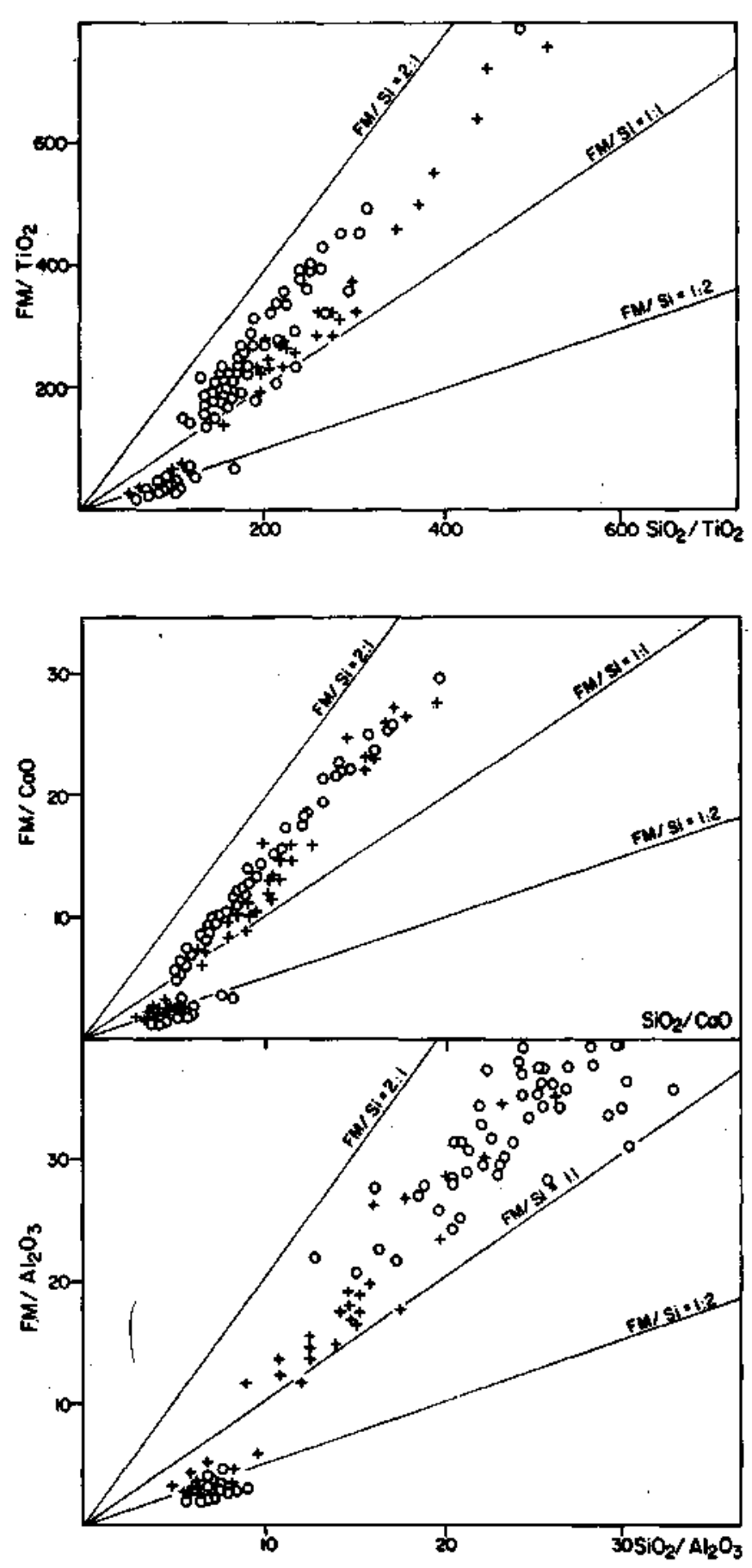

Figure 6 - Molecular proportion ratio plots (MPR or Pearce plots) of $\mathrm{SiO}_{2} / \mathrm{CaO}$ versus $\mathrm{FM} / \mathrm{CaO}, \mathrm{SiO}_{2} / \mathrm{TiO}_{2}$ versus $\mathrm{FM} / \mathrm{TiO}_{2}$ and $\mathrm{SiO}_{2} \mathrm{O}_{3} / \mathrm{Al}_{2} \mathrm{O}_{3}$ versus $\mathrm{Fm} / \mathrm{Al}_{2} \mathrm{O}_{3} . \mathrm{FM}=$ $\mathrm{FeO}+\mathrm{MgO}$. The lines $\mathrm{FM} / \mathrm{Si}=2: 1,1: 1$, and $1: 2$ are reference lines for olivine, orthopyroxene and clinopyroxene respectively, drawn to pass through the origin, although this does not applies in natural cases. The komatiites of Crixás (circles) and Hidrolina (crosses, clearly show the influence of olivine as a control phase

Figura 6 - Diagramas de quocientes de proporções moleculares (Diagramas MPR ou de Pearce) de $\mathrm{SiO}_{2} / \mathrm{CaO}$ versus $\mathrm{Fm} / \mathrm{CaO}$, $\mathrm{SiO}_{2} / \mathrm{TiO}_{2}$ versus $\mathrm{FM} / \mathrm{TiO}_{2}$ e $\mathrm{SiO}_{2} / \mathrm{Al}_{2} \mathrm{O}_{3}$ versus $\mathrm{FM} / \mathrm{Al}_{2} \mathrm{O}_{3}$. $\mathrm{FM}=\mathrm{FeO}$ $+\mathrm{MgO}$. As linhas $\mathrm{FM} / \mathrm{Si}=2: 1,1: 1$ e 1:2 são linhas de referência para olivina, ortopiroxênio e clinopiroxênio respectivamente, desenhadas para passar pela origem, embora isto não se aplique em casos naturais. Os komatiftos de Crixás (círculos) e Hidrolina (cruzes) mostram claramente a influência da olivina como fase de controle 
Mantle heterogeneities are evidenced by the behaviour of many incompatible or moderatey compatible trace elements (Ti, Y, Sc, Zr, V and P) and are probably consistent with a modal variation in the spinel content, higher in the Crixas than in the Hidrolina mantle.

The Crixás sequence shows many of the characteristics found in belts older than 3.5 Ga (Arndt et al. 1989 and references therein), such as low $\mathrm{Al}_{2} \mathrm{O}_{3} / \mathrm{TiO}_{2}$ ratio, whereas the Hidrolina sequence is more similar in this respect to younger $(2.7 \mathrm{Ga})$ belts.

A variability of the mantle source cannot, however, account for the differences in the $\mathrm{CaO}$ and $\mathrm{Al}_{2} \mathrm{O}_{3}$ behaviours (with respect to $\mathrm{MgO}$ ). Their anomalous trends at Crixás have been tentatively attributed to a poorly constrained magmatic process, which implies clinopyroxene growth into an olivine mush. This process eventually has acted at Crixás and not at Hidrolina. Other possibilities, such as metamorphic open system, would imply differences in the metamorphism of the two areas, which is unsupported by the petrographic observations, whereas contamination of the magmas by crustal material is unsupported by the trace elements behaviour.

Acknowledgemens Mrs. Daniela Rabitti, who has contributed to carry out the analytical work, is gratefully acknowledged.

This work has been financially supported by the Italian agencies CNR and Ministero Pubblica Istruzione and by the Brazilian agencies FINEP, FAPESP and CNPq.

\section{REFERENCES}

AITKEN, B. \& ECHEVERRIA, L.M. 1984. Petrology and geochemistry of komatiites and tholeiites from Gorgona Island, Colombia Contr. Miner Petrol., 86:94-105.

ALMEIDA, F.F.M. de \& HASUI, Y. 1969. Idades potássio-argônio de rochas do centro-oeste brasileiro. In: CONOR. BRAS. GEOL., 23, Salvador, 1969. Resumo das conferências e das comunicações... Salvador, SBG. v.1, p. 80-81. (Boletim Especial).

ARNDT, N.T. 1976. Melting relations of ultramafic lavas (komatiites) at one atmosphere and high pressure. Carnegie Inst. Washington Yearbook, 75:555-561.

ARNDT, N.T.; TEIXEIRA, N.A.; WHITE, W.N. 1989. Bizarre geochemistry of komatiites from the Crixás greenstone belt Contr. Miner. Petrol. 101:187-197.

BBS WICK, A.E. 1982. Some geochemical aspects of alteration and genetic relations in komatiitic suites. In: ARNDT, N.T. \& NISBET, E.G. ed. Komatiites. London, G. Allen and Unwin. p.283-308.

DANNI, J.C.M. \& RIBEIRO, C.C. 1978. Caracterização estratigráfica da seqüência vulcano-sedimentar de Pilar de Goiás e Guarinos, Goiás. In: CONGR. BRÁS. GEOL., 30, Recife, 1978. Anais... Recife, SBG. v.2, p.582-597

DANNI, J.C.M.; JOST, H.; WINGE, M.; ANDRADE, G.F. 1986. Aspectos da evolução de terrenos granito-greenstone: exemplo da região Hidrolina, Goiás. In: CONGR. BRÁS. GEOL., 35, Goiânia, 1986. Anais... Goiânia, SBG. v.2 p.570-584.

GREEN, D.H.; NICHOLLS, A.; VILJOEN, M.; VILJOEN, R. 1975. Experimental demonstration of the existence of peridotitic liquids in earliest Archaean magmatism. Geology, 3:11-14.

HOFMANN, A.W. 1988. Chemical differentiation of the Earth: the relationship between mantle, continental crust, and oceanic crust. Earth Planet. Set. Letters., 90:297-314.

HASUI, Y. \& ALMEIDA, F.F.M. de 1970. Geocronologia do centro-oeste brasileiro. Bol. da Soc. Bras. Geol., 19:5-26.

JAGOUTZ, E.; PALME, H.; BADDENHAUSEM, H.; BLUM, K. CE NDALES, M.; DREIBUS, G.; SPETTEL, B.; LORENZ, V.; WÃNKE, H. 1979. The abundances of major, minor and trace elements in the earth's mantle as derived from primitive ultramafic nodules. Proc. Lunar Planet Sci Conf 10:2031-2050.

JOST, H.; VARGAS, M.C.; GUGELMIN, V.; OLIVEIRA, S.R.M 1989. Seqüência Morro Escuro. Uma nova unidade estratigráfica do Arqueano/Proterozóico Inferior da Região de Crixás. Estado de Goiás. Rev. Bros. Geoc. 19(3):283-289.

JOST, H. \& OLIVEIRA, A.M. 1990. Stratigraphy of the Greenstone Belts of the Crixás Region, Goiás, Central Brazil. Journ. South Amer. Earth Sci. (in press).

KINZLER, R.J. \& GROVE, T.L. 1985. Cristallization and differentiation of Archean komatiitc lavas from northeast Ontario: phase equilibrium and kinetic studies. Am. Mineral. 70:40-51.

MAGALHÃES, L.F.; CASTRO, J.H.C. de; BORGES, O.C. 1984 Geologia, prospecção e pesquisa de ouro no greenstone belt de Crixás. Algumas considerações. In: ENCONTRO REGIONAL DE OURO DE GOIÁS, 1, Goiânia, 1984. Anais... Goiânia, SBG. p.26-57

MONTALVÃO, R.M.G. 1986. Evolução geotectônica dos terrenos granitóides-greenstone belts de Crixás, Guarinos, Pilar de Goiás-Hidrolina. In: CONGR. BRÁS. GEOL., 35, Goiânia, 1986. Anais... Goiânia, SBG. v.2, p.585-596.

NESBITT, R.W. \& SUN, S.S. 1980. Geochemical features of some Archaean and post-Archaean high-naagnesian - low-alkali liquids. PM. Trans. R. Soe. Land., 297:229-242.
NISBET, E.G.; ARNDT, N.T.; BICKLE, MJ.; CAMERON, W.E.; CHAUVEL, C.; CHEADLE, M.; HEGNER, E.; KYSER, T.K.; MARTIN, A.; RENNER, R; ROEDDER, R 1987. Uniquely fresh 2.7 Ga komatiites from the Belingwe greenstone belt, Zimbabwe. Geology, 15:1147-1150.

PEARCE, T.H. 1968. A contribution to the theory of variation diagrams. Contr. Miner. Petrol., 19:142-157.

PEARCE, T.H. 1987. The identification and assessment of spurious trends in Pearce-type ratio variation diagrams: a discussion of some statistical arguments. Contr. Min. Petrol., 97:529-534.

RIBEIRO FILHO, W. 1978. Projeto geologia da região de Pilar-Mara Rosa; relatório final. Goiânia, DNPM/CRPM. (Relatório do Arquivo Técnico da DGM, 2784).

RIBEIRO FILHO, W. 1984. Geologia e alguns aspectos das mineralizações aurfferas das faixas Pilar e Guarinos. In: ENCONTRO REGIONAL DE OURO DE GOIÁS, 1, Goiânia, 1994. Anais... Goiânia, SBG p.6-25.

RIVALENTI, G. GIRARDI, V A.V · COLTORTI, M., CORREIA, C.T.; MAZZZUCCHELLI, M. 1989. Geochemical models for the petrogenesis of komatiites from the Hidrolina greenstone belt. $J$. Petrology, 30:175-198.

ROLLINSON, H.R. \& ROBERTS, C.R. 1986. Ratio correlations and major element mobility in altered basalts and komatiites. Contr. Mineral. Petrol., 93:89-97.

RUSSEL, J.K. \& NICHOLS, J. 1988. Analysis of petrologic hypoteses with Pearce element ratios. Contr. Miner. Petrol., 99:25-35.

SABOIA, L.A. \& TEIXEIRA, N.A. 1983. Ultramafic flows of the Crixás greenstone belt, Goiás - Brazil. Precambrian Res., 22:23-40.

SABOIA, L.A.; TEIXIERA, N.A.; CASTRO J.H.G.; TEIXEIRA, A.S. 1979.Geologia do "greenstone belt" de Crixás (GO) e suas implicacões geotectônicas. In: SIMP. SOBRE O CRÁTON DE SÃO FRANCISCO E SUAS FAIXAS DOBRADAS MARGINAIS, 1, Salvador, 1969Anais... Salvador, SBG. p. 39-50.

SHERVAIS, J.W. 1982. Ti-V plots and the petrogenesis of modera and ophiolitic lavas. Earth Planet. Sci. Letters, 59:101 -118.

TASSINARI, C.C.G. \& MONTALVÃO, R.M.G. 1980. Estudo geocronológico do Greenstone Belt de Crixás. In: CONGR. BRÁS. GEOL., 31, Balneário de Camborhí, 1980. Anais... Camborid, SBG. v.5, p.2752-2759.

VILJOEN, M.J.; VILJOEN, R.P.; PEARTON, T.N. 1982. The nature and distribution of Archaean komatiite volcanics in South Africa. In: ARNDT, N.T. \& NISBET, E.G. ed. Komatiites. London, G. Allen and Unwin. p.53-79.

WÃNKE, H.; BADDENHAUSEN, H.; PALME, H.; SPETTEL, B. 1974. On the chemistry of the Allende inclusions and their origin as high temperature condensates. Earth Planet. Sci. Letters, 23:1-14.

WOOD, D.A. 1979. A variably veined suboceanic upper mantle-genetic significance for mid-ocean ridge basalts from geochemical evidence. Geology, 7:499-503. 